\title{
Caryodaphnopsis fieldii (Lauraceae), a New Species from the Coastal Cordillera of Venezuela
}

\author{
Gerardo A. Aymard C. \\ UNELLEZ-Guanare, Programa de Ciencias del Agro y del Mar, Herbario Universitario (PORT), \\ Mesa de Cavacas, Estado Portuguesa 3350, Venezuela. gaymard@cantv.net
}

\section{Gustavo A. Romero-González}

Orchid Herbarium of Oakes Ames, Harvard University Herbaria, 22 Divinity Avenue, Cambridge, Massachusetts 02138, U.S.A. romero@oeb.harvard.edu

Abstract. A new species of Caryodaphnopsis Airy Shaw from Henri Pittier National Park, in the Coastal Cordillera of Aragua State, Venezuela, is described and illustrated, and its morphological relationships with allied species are discussed. Caryodaphnopsis fieldii Aymard \& G. A. Romero resembles C. fosteri van der Werff, but it is distinguished by leaves with densely puberulent petioles and a rounded apex, pedicels 2-3 mm long, inner tepals $3-4.5 \mathrm{~mm}$ long and densely sericeous inside, stout filaments ca. $2 \mathrm{~mm}$ long, inner stamens with two globose glands attached at the base, and the pubescent ovary. Geographical information about the Coastal Cordillera region and a key to the Neotropical species of Caryodaphnopsis are presented. This species represents the first report of this genus for Venezuela.

Resumen. Una nueva especie de Caryodaphnopsis Airy Shaw del Parque Nacional Henri Pittier, en la Cordillera de la Costa, estado Aragua, Venezuela, es descrita e ilustrada, y sus relaciones morfológicas con las especies afines son discutidas. Caryodaphnopsis fieldii Aymard \& G. A. Romero es similar a C. fosteri van der Werff, sin embargo, se diferencia de esta especie por sus pecíolos densamente puberulentos, el ápice redondeado; los pedicelos 2-3 mm de largo; los tépalos internos 3-4.5 mm de largo, densamente seríceos internamente, los filamentos gruesos, ca. $2 \mathrm{~mm}$ de largo, los estambres internos con dos glándulas globosas situadas en la base del filamento, y el ovario pubescente. Se presenta información geográfica acerca de la Cordillera de la Costa y una clave de las especies Neotropicales de Caryodaphnopsis. Esta nueva especie representa el primer registro del género para Venezuela.

Key words: Caryodaphnopsis, Coastal Cordillera, IUCN Red List, Lauraceae, Venezuela.

Caryodaphnopsis Airy Shaw is a tropical amphiPacific genus of Lauraceae (van der Werff \& Richter,
1985) that shows a remarkable disjunction between Southeast Asia (southern China, Vietnam, Laos, Cambodia, the Philippines, and Indonesia) and tropical America (Costa Rica, Panama, Colombia, Ecuador, Peru, and Brazil, and reported herein for Venezuela). Caryodaphnopsis is characterized among genera of Lauraceae by its opposite leaves and six strongly unequal tepals, the outer three being much smaller than the inner three (van der Werff \& Richter, 1985; van der Werff, 199la; van der Werff \& Dao, 1999). In addition, Caryodaphnopsis has an interesting wood anatomical feature: the presence of pyramidal calcium oxalate crystals in the ray parenchyma cells (Richter, 1981; van der Werff \& Richter, 1985), which is present in the Old World species of the genus, but not found in the Neotropical species (F. Lorea, pers. comm., 2008). Most species have 4locellate anthers (vs. 2-locellate in other Caryodaphnopsis [vs. other Lauraceae]), nine stamens (vs. six), and tripliveined leaves (vs. penniveined).

\section{The Coastal Cordillera}

The Coastal Cordillera (Cordillera de la Costa) is the third largest mountain range in Venezuela, extending approximately $800 \mathrm{~km}$ from its western extreme in the Turbio-Yaracuy depression, where it separates from the Venezuelan Andes, to its eastern end at the tip of the Peninsula de Paria in the state of Sucre. Because of their proximity, the Coastal Cordillera and the Venezuelan Andes have sometimes been considered a continuous mountain chain. However, these two cordilleras do not share a common geologic history; the Coastal Cordillera is ca. 65 million years old, whereas the northern Andes complex is ca. 20 million years old (González de Juana et al., 1980; F. Urbani, pers. comm., 2006). The northern limit of the Coastal Cordillera is the Caribbean coastline, and to the south we find vast plains known as Los Llanos. The summits and 


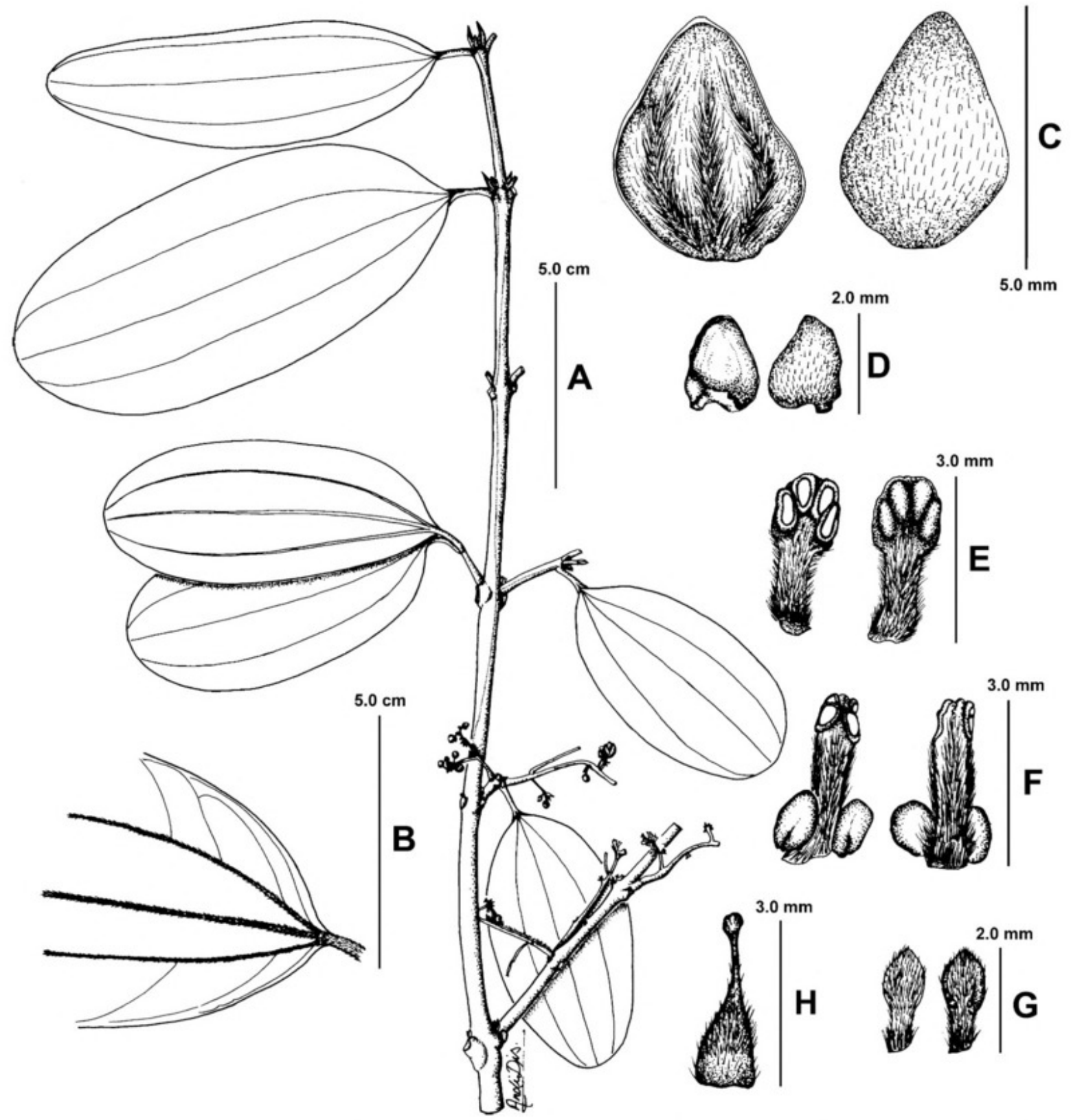

Figure 1. Caryodaphnopsis fieldii Aymard \& G. A. Romero. -A. Branch with leaves and inflorescences. -B. Basal portion of a leaf, showing the sparse pilosity on the abaxial side, more dense along the main and secondary veins, and the dense, short pubescence on the petiole. -C. Inner tepals. -D. Outer tepals. -E. Outer stamens. -F. Inner stamens. -G. Staminodia. -H. Ovary. Drawn from the isotype A. Field 442 (NY).

uppermost slopes of the Coastal Cordillera are mostly covered by humid cloud forest, which extend between 600 and $2000 \mathrm{~m}$. Deciduous and humid low forest are also found in this region, scrub and low forests are present in the arid coastal region, and savannas and herbaceous formations occur on lower slopes, mainly in the interior valleys and plains. Steyermark (1982) studied the Coastal Cordillera flora and concluded that, in addition to endemic taxa, the vegetation of this region was a blend of Central American, Caribbean, Andean, and Guayanan-Amazonian elements. According to Huber et al. (1998), the region holds between
3000 and 3500 species of vascular plants, of which ca. 278 were noted as endemic.

Caryodaphnopsis fieldii Aymard \& G. A. Romero, sp. nov. TYPE: Venezuela. Aragua: Distrito Girardot, Parque Nacional Henri Pittier, cloud forest, 1180 m, July 1984, A. Field 442 (holotype, MY; isotypes, MERF, NY). Figure 1.

Species Caryodaphnopsidi fosteri van der Werff accedens, sed ab ea petiolis dense puberulis, foliis apice rotundatis, pedicellis $2-3 \mathrm{~mm}$ longis, tepalis interioribus $3-4.5 \mathrm{~mm}$ 
longis, intus dense sericeis, filamentis validis ca. $2 \mathrm{~mm}$ longis, antheris interioribus glandulis globosis duabus basi adhaerentibus atque ovario pubescente diversa.

Tall trees; twigs quadrangular to slighty terete, densely puberulent, glabrescent when mature. Leaves opposite, chartaceous, elliptic to elliptic-oblong, 6-12 $\times 3-6 \mathrm{~cm}$, base acute to cuneate, apex rounded, glabrous adaxially, sparsely pilose abaxially, more densely along the main and secondary veins; blades triplinerved, the basal lateral veins leaving the midrib $1-3 \mathrm{~mm}$ from the base of the leaf, lateral and secondary venation slightly impressed adaxially, raised abaxially, tertiary venation immersed on both surfaces; petioles 6-12 mm, densely short pubescent. Inflorescence axillary, paniculate with alternate branches, $2.5-5 \mathrm{~cm}$; peduncles ridged, sparsely pilose; flowers pediceled, pedicels $2-3 \mathrm{~mm}$, densely adpressed pubescent, with 2 triangular bracteoles at the base. Tepals 6 , strongly unequal, the outer $31-$ $2 \mathrm{~mm}$, wide-ovate, sparsely strigose externally, glabrous internally, the inner $33-4.5 \mathrm{~mm}$, ovate, 6veined, adpressed pilose externally, densely sericeous internally; fertile stamens 9; filaments ca. $2 \mathrm{~mm}$, stout, densely sericeous; anthers 4-locellate, the locelli arranged in 2 horizontal rows with the lower pair larger than the upper, introrse in the outer 6 stamens, extrorse in the inner 3, these with 2 globose glands attached at the base; staminodia $3,1.5-2 \mathrm{~mm}$, filaments densely sericeous, tip triangular; ovary ca. $1 \mathrm{~mm}$, sparsely pilose at the base, strigose from the middle to the apex; style ca. $1 \mathrm{~mm}$, slender; stigma capitate. Fruit not seen.

Distribution and habitat. Caryodaphnopsis fieldii is known only from the type specimen, collected in Aragua State, Venezuela, in the central portion of the Coastal Cordillera, in moist montane forests dominated by trees of Gyranthera caribensis Pittier (Malvaceae) that are up to $50 \mathrm{~m}$ tall (Huber, 1986; Smith \& Field, 2001). It may be common in this area, but the great height of the trees surely has discouraged collectors.

IUCN Red List category. According to IUCN Red List criteria (IUCN, 2001), the new species should be included in the category LC (Least Concern) at the regional level, because it is legally protected within Henry Pittier National Park, Aragua State, Venezuela.

Etymology. The specific epithet honors the collector of the type, Andrew M. Field (1955-1984), pioneer of forest canopy studies in Venezuela, who died when he accidentally fell from a Gyranthera caribensis tree while conducting canopy research in August 1984 (Bordón, 1987).

Discussion. Caryodaphnopsis fieldii shares the following characters with $C$. fosteri: rachis of the inflorescence and pedicels sparsely to densely adpressed pubescent, inflorescences not longer than $6 \mathrm{~cm}$, and ovary ca. $1 \mathrm{~mm}$ long. However, C. fieldii is distinguished from $C$. fosteri by petioles densely short pubescent (vs. slightly pilose); apex of the leaves rounded (vs. obtuse to acute); pedicels $2-3 \mathrm{~mm}$ long (vs. ca. $5 \mathrm{~mm}$ long); inner tepals $3-4.5 \mathrm{~mm}$ long, densely sericeous inside (vs. 5-6 mm long, pilose inside); filaments stout, ca. $2 \mathrm{~mm}$ long (vs. slender, 3$4 \mathrm{~mm}$ long); the inner stamens with two globose glands attached at the base (vs. two glands attached ca. $1 \mathrm{~mm}$ above the base); and the ovary pubescent (vs. glabrous).

Including the new species described here, Caryodaphnopsis currently comprises 15 species. The Asian species were revised by Kostermans (1974), and a key for known species was written in Chinese by Li and Li (1991). Since Kostermans revised the Asian species, eight new species (including $C$. fieldii) have been described in or transferred to Caryodaphnopsis, one from Vietnam and the others from the Neotropics (van der Werff \& Richter, 1985; van der Werff, 1986, 1988, 1991b; van der Werff \& Dao, 1999; Zamora et al., 1988). However, the genus as a whole has never been revised. The following key facilitates the identification of the Neotropical species. It is based on original descriptions and on the examination of specimens deposited in the New York Botanical Garden, the Missouri Botanical Garden, and the Harvard University Herbaria.

\section{Key to THE NeOtropical SPECIES OF CARYODAPHNOPSIS}

la. Leaves penniveined.

2a. Anthers 2-celled; leaves oblong to elliptic, not glaucous abaxially; Amazonian Brazil, Peru, Colombia ..... $\ldots \ldots \ldots \ldots \ldots \ldots \ldots \ldots \ldots \ldots \ldots \ldots \ldots \ldots \ldots$ inaequalis (A. C. Smith) van der Werff \& H. G. Richter

2b. Anthers 4-celled; leaves elliptic, gray-glaucous to glaucous abaxially.

3a. Apex of the leaf acute; rachis of the inflorescence ferruginous pubescent; filaments glabrous; Antioquia,

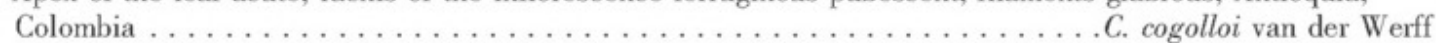

3b. Apex of the leaf mainly obtuse, sometimes acute; rachis of the inflorescence puberulent; filaments pubescent; Colombia, Ecuador. . . . . . . . C. theobromifolia (A. H. Gentry) van der Werff \& H. G. Richter 1b. Leaves tripliveined.

4a. Leaves glaucous abaxially; Colombia, Ecuador .. C. theobromifolia (A. H. Gentry) van der Werff \& H. G. Richter 4b. Leaves not glaucous abaxially. 
5a. Flowers with 6 fertile stamens; leaves coriaceous, densely brown tomentose abaxially; Ecuador, Peru .. .

$\ldots \ldots \ldots \ldots \ldots \ldots \ldots \ldots \ldots \ldots \ldots \ldots \ldots \ldots \ldots \ldots \ldots \ldots$ tomentosa $\operatorname{van}$ der Werff

5b. Flowers with 9 fertile stamens; leaves chartaceous to subcoriaceous, sparse to densely shortly pilose abaxially.

6a. Leaf apex acute or acuminate to cuspidate; inner tepals 7-10 mm long; ovary ca. $1.9 \mathrm{~mm}$ long with sparse sericeous pubescence; Costa Rica, Panama . . . . . . . . . C. burgeri N. Zamora \& Poveda

6b. Leaf apex acute or rounded; inner tepals $3-6 \mathrm{~mm}$ long; ovary ca. $1 \mathrm{~mm}$ long, glabrous or pubescent.

7a. Petioles slightly pilose; pedicels ca. $5 \mathrm{~mm}$ long; inner tepals $5-6 \mathrm{~mm}$ long, sparsely pilose inside; filaments slender, $3-4 \mathrm{~mm}$ long; the inner stamens with 2 globose glands attached ca. $1 \mathrm{~mm}$ above the base; ovary glabrous; Colombia, Ecuador, Peru, Bolivia . . C. fosteri van der Werff

7b. Petioles densely short pubescent; pedicels $2-3 \mathrm{~mm}$ long; inner tepals $3-4.5 \mathrm{~mm}$ long, densely sericeous inside; filaments stout, ca. $2 \mathrm{~mm}$ long; the inner stamens with 2 globose glands attached at the base; ovary pubescent; Coastal Cordillera, Venezuela. . . . . . . . . . . . $\ldots \ldots \ldots \ldots \ldots \ldots \ldots \ldots \ldots \ldots \ldots \ldots \ldots \ldots \ldots \ldots \ldots \ldots \ldots \ldots \ldots$ fieldii Aymard \& G. A. Romero

Acknowledgments. We thank H. van der Werf, S. Madriñan, F. G. Lorea, and V. C. Hollowell for comments on the manuscript, and Bruno Manara for revising the Latin description. We are grateful to $\mathrm{A}$. Licata for preparing the illustration, to Otto Huber for supplying literature, and to the New York Botanical Garden and the Missouri Botanical Garden for making their facilities available for our research.

\section{Literature Cited}

Bordón, C. A. 1987. Andy: Vida de un Botánico Inglés en la Selva Nublada de Rancho Grande, Venezuela. Multimar S.R.L., Maracay, Aragua.

González de Juana, C., J. M. Iturralde de Arozena \& X. Picard-Cadillat. 1980. Geología de Venezuela y de sus Cuencas Petrolíferas. Ediciones FONINVES, Caracas.

Huber, O. 1986. Las selvas nubladas de Rancho Grande: Observaciones sobre su fisionomía, estructura y fenología. Pp. 131-170 in O. Huber (editor), La Selva Nublada de Rancho Grande Parque Nacional Henri Pittier: El Ambiente Físico, Ecología Vegetal y Anatomía Vegetal. Fondo Editorial Acta Científica Venezolana, Editorial Arte, Caracas.

R. Duno de Stefano, R. Riina, R. F. Stauffer, L.

Pappaterra, A. Jiménez, S. Llamozas \& G. Orsini. 1998. Estado actual del conocimiento de la Flora de Venezuela. Documento Técnico de la Estrategia Nacional de Diversidad Biológica. Ministerio del Ambiente y de los Recursos Naturales Renovables-Fundación Instituto Botánico, Caracas. IUCN. 2001. IUCN Red List Categories and Criteria, Version 3.1. Prepared by the IUCN Species Survival Commission. IUCN, Gland, Switzerland, and Cambridge, United Kingdom.
Kostermans, A. J. G. H. 1974. A monograph of Caryodaphnopsis A. Shaw. Reinwardtia 9: 123-137.

Li, X.-W. \& J. Li. 1991. Notes on the taxonomy and distribution of the genus Caryodaphnopsis of Lauraceae and to discuss the characteristics of its area-type. Acta Bot. Yunnan. 13: 1-13.

Richter, H. G. 1981. Anatomie des sekundren Xylems und der Rinde der Lauraceae. Sonderb. Naturwiss. Vereins Hamburg 5: 1-148.

Smith, R. F. \& A. Field. 2001. Aspectos de la ecología de Gyranthera caribensis Pittier (Bombacaceae) y su implicación en la conservación de algunos bosques del norte de Venezuela. Acta Bot. Venez. 24: 143-202.

Steyermark, J. A. 1982. Relationships of some Venezuelan forest refuges with lowland tropical floras. Pp. 182-220 in G. T. Prance (editor), Biological Diversification in the Tropics. Columbia University Press, New York.

van der Werff, H. 1986. A new species of Caryodaphnopsis (Lauraceae) from Peru. Syst. Bot. 11: 415-418.

1988. Eight new species and one new combination of Neotropical Lauraceae. Ann. Missouri Bot. Gard. 75: 402-419.

1991a. A key to the genera of Lauraceae in the New World. Ann. Missouri Bot. Gard. 78: 377-387.

. 1991b. New species of Lauraceae from Ecuador and Peru. Ann. Missouri Bot. Gard. 78: 409-423.

\& H. G. Richter. 1985. Caryodaphnopsis Airy Shaw, a genus new to the Neotropics. Syst. Bot. 10: 166-173.

\& N. K. Dao. 1999. A new species of Caryodaphnopsis (Lauraceae) from Vietnam. Novon 9: 584-586.

Zamora, N., L. J. Poveda \& E. Canessa A. 1988. Una nueva especie de Caryodaphnopsis Airy Shaw (Lauraceae) para la región Neotropical. Ann. Missouri Bot. Gard. 75: $1160-1166$. 


\section{$2 \mathrm{BHL}$ Biodiversity Heritage Library}

Aymard C., Gerardo A. and Romero-González, Gustavo A. 2009.

"Caryodaphnopsis fieldii (Lauraceae), a New Species from the Coastal

Cordillera of Venezuela." Novon a journal of botanical nomenclature from the Missouri Botanical Garden 19, 7-10.

View This Item Online: https://www.biodiversitylibrary.org/item/124658

Permalink: https://www.biodiversitylibrary.org/partpdf/121866

\section{Holding Institution}

Missouri Botanical Garden, Peter H. Raven Library

\section{Sponsored by}

Missouri Botanical Garden

\section{Copyright \& Reuse}

Copyright Status: Permission to digitize granted by rights holder Rights: https://www.biodiversitylibrary.org/permissions

This document was created from content at the Biodiversity Heritage Library, the world's largest open access digital library for biodiversity literature and archives. Visit BHL at https://www.biodiversitylibrary.org. 